\title{
A CONSTRUÇÃO DA IMAGEM DO PODER EM TEXTOS JURÍDICOS DA IDADE MÉDIA PENINSULAR
}

\section{The construction of the image of power in legal texts of the Middle Ages}

\author{
Prof. Dra. Clara Barros (Universidade do Porto) \\ Docente da Graduação e Pós-Graduação da Faculdade de Letras da Universidade do Porto \\ Department of Portuguese and Romance Studies \\ ORCID: http://orcid.org/0000-0002-4118-1683
}

E-mail: mbarros@ letras.up.pt

Recebido em: 22/07/2020

Aprovado em: 04/09/2020

\begin{abstract}
Resumo: Proponho-me fazer, neste artigo, a análise linguístico-discursiva de dois textos jurídicos medievais - Primeyra Partida e Foro Real, de Afonso X, o Sábio -, procurando observar e descrever algumas estratégias de persuasão características da obra legislativa de Afonso X que evidenciam a relação da construção retórica com o poder político, na Idade Média peninsular (séculos XIII e XIV). Centro a minha análise na estruturação e funcionamento destes textos - ou dos discursos neles patentes -, recorrendo a elementos teóricos e instrumentos metodológicos que se inscrevem genericamente na Pragmática Linguística, tendo necessariamente em consideração as suas conexões com a Teoria da Argumentação e a Retórica. O uso de argumentos de autoridade, a invocação de exemplos e de estruturas analógicas com recurso a modelos naturais, eram doutrina retórica sobejamente conhecida na época da redação dos textos jurídicos aqui analisados e típica de textos destinados à pregação, mas não exclusiva destes. Na legislação, pretende-se conduzir o Alocutário a uma determinada prática: há, portanto, razões para crer que o "género retórico" que visava o convencimento/sedução, estabelecido ao longo dos séculos na prática sermonística, não era exclusivo da pregação de carácter religioso, sendo também utilizado nos textos jurídicos desde meados do século XIII.
\end{abstract}

Palavras-chave: argumentação, retórica, textos jurídicos medievais peninsulares, Afonso X

Abstract: The article intends to analyse, from a linguistic-discursive perspective, two of Afonso X's legislative texts, those of the Primeyra Partida and the Foro Real. In this study I intend to analyse some strategies of the persuasion characteristic of Afonso X - the Wise's legislative work which reveal a certain relationship between rhetorical construction and political power in the Peninsular Middle Ages (in the 13th and 14th centuries). I have focused my analysis on the structuring and functioning of these texts - or of the speeches shown in them -, using theoretical elements and methodological instruments which are generally used in Linguistic Pragmatics (necessarily taking into account their connections with the Theories of Argumentation and Rhetoric). The use of arguments of authority, the invocation of examples and analogical structures using natural models was a rhetorical doctrine which was doubtless well known at the time the legal texts analysed here were being written; it was a use typical of texts intended for preaching, but not exclusive to them. In the legislation discussed in these texts, the addressee is intended to follow a given practice. It is therefore possible that this "rhetorical genre" which aims to convince / seduce, and which was established during centuries in sermonistic practice, was not exclusive to preaching of a religious nature, since it was also used, since the middle of the $13^{\text {th }}$ century, in legal texts.

Key-words: Argumentation; rhetoric, medieval Iberian juridical texts; Alphonse X 
Pretendo analisar, neste estudo, ${ }^{1}$ algumas estratégias de persuasão características da obra legislativa de Afonso X, o Sábio, que revelam a relação da construção retórica com o poder político, na Idade Média peninsular (séculos XIII e XIV). Observei um corpus de textos legislativos constituído por versões portuguesas de obras da legislação de Afonso X, o Sábio ${ }^{2}$. Serão analisados os textos da Primeyra Partida e do Foro Real ${ }^{3}$ que se integram, ambos, numa nova tradição discursiva de produção de grandes compilações de leis que testemunha uma enorme atividade de produção de obras jurídicas na Península Ibérica, durante a Idade Média.

Trata-se de textos em que se observam dois tipos de discurso: o discurso legislativo propriamente dito - 'expositivo' - de teor prescritivo; e um 'discurso legislativo justificativo' que é predominantemente realizado em atos assertivos, com função de explicação-justificação, em que é evidente a presença de estratégias de argumentação. Nesse discurso de justificação são utilizados recursos retóricoargumentativos que apresentam semelhanças com os que utiliza o discurso da pregação. Tal afinidade indicia que se tratava de doutrina retórica disponível e reconhecida na época da redação dos textos jurídicos aqui analisados e característica das artes de pregar, mas não exclusiva destes. Na legislação patente nestes textos, tal como na pregação, há uma intenção de interferir nas crenças do Alocutário e, sobretudo, orientar uma determinada praxis.

É notório que nestes primeiros códigos de leis se afirmam como diferentes e inovadoras em relação a anteriores formulações legislativas. Pretendem substituir legislação consuetudinária, coletâneas de forais diversos e dispersos e as sentenças referentes a casuística anterior e consideradas modelares, as façanhas. Procede-se a uma avaliação crítica da situação anterior, em que vigorava uma administração da justiça desencontrada e não fundamentada que conduzia a um mal-estar da população e a um quadro indesejável para a comunidade, como se pode observar no seguinte excerto do Foro Real:

[...] nos dõ Affonso pella graça de Deus rey de Castella e de Tuledo e de Leõ [...] entẽdendo que muytas cydades e muytas uilhas e castellos de nossos reynos non ouuerõ foro ata o nosso tempo e juygassẽ per façanhas e por aluidros departidus dos omees e per usos desguysados e sen dereyto de que uijã muytos danos e muytos maes aos omees e a todo o poboo [...] demuslhys este foro que é scripto eneste livro [...] (FoR, I, 25-37)

A exposição da legislação agora proposta é acompanhada da justificação retórica da sua pertinência. Os textos inserem-se num quadro ideológico de valorização da ação legislativa régia e afixam uma justificação dos fundamentos da legitimidade dessa ação, baseando-se em modelos que asseguravam o sucesso comunicativo. É o reforço do poder real, sobretudo no século XIII, que vai permitir a produção legislativa emanada da autoridade régia, com recurso ao direito romano e canónico, na tentativa de substituir o direito consuetudinário local. O historiador português José MATTOSO (1985-6, I: 52, nota 6) chama a atenção para o carácter tardio da função do Estado como "detentor exclusivo do Direito e Poder Públicos" e para a dificuldade de emergência desse elemento aglutinador que se torne "a encarnação de ideais coletivos de justiça e de equidade" afirmando que "o Estado não se impõe sem fortes resistências" (MATTOSO, 1985-6, I: 60-61).

De facto, legislar é uma prerrogativa régia. Trata-se de um discurso do poder, mas a instância do poder sente agora a necessidade de explicar e de justificar as diretivas 
propostas. Nesse quadro da luta entre os poderes locais e o poder central, os textos da legislação de Afonso $X$ constituem uma tentativa de organização estatal do aparelho judicial, de centralização do poder em tempo de feudalismo. É neste cenário ideológico que se produz um discurso de autoridade que utiliza diversas estratégias retóricas para a construção da sua legitimidade que assenta na demonstração da legitimidade do poder da figura de que emana. A autoridade do rei surge justificada pela sua origem divina, de que decorre igualmente a sua sabedoria. Mas está também reforçada por uma imagem da estruturação do poder temporal em que o rei é metaforicamente definido como "cabeça de seu povo" e como a entidade que "mantem o povo em paz", assegurando a promoção do bem e o castigo do mal.

É defendido, nestes textos, o modelo hierárquico do poder régio e a sua legitimação é feita com recurso à autoridade divina, afirmando-se explicitamente a estreita relação entre Deus e as leis. O discurso jurídico é visto como emanando de uma autoridade, sendo Deus é considerado a autoridade suprema. Por isso, a autoridade divina é a que se salienta entre todas, sendo também a mais frequentemente invocada.

Estabelece-se este fundamento logo no início do texto, como acontece no Prólogo da Primeyra Partida:

Deus he começo e meyhao e acabamẽto de todalas cousas e sen el nõ pode nẽ hũa cousa seer ca pelo seu poder e pelo seu saber som todas feytas e gouernadas e pola sa bondade manteudas.

(PrP, Pról., 8-11)

A doutrina da origem divina do poder régio e da transferência de poderes surge muito claramente, quer no texto da Primeyra Partida, quer no do Foro Real. Basta referir que em ambos os textos, e logo no início, o rei se auto designa através da consagrada fórmula:

E por ende nos don Affomsso pela graça de Deus rrey de Castela e de Leo e de Galiza e de Sevilha $[\ldots]$.

(PrP, Pról., 14-15)

E porende nos dõ Affonso pella graça de Deus rey de Castela e de Tuledo e de Leõ e de Gualiza [...].

$(F o R$, I, 25-264)

São muito numerosas as referências a esta "graça" divina, ou seja, à tese da origem divina do poder temporal, por desígnio de Deus. E temos uma situação discursiva assimétrica, que se estabelece quando o Locutor- Rei é mais forte, tem um lugar mais elevado, uma melhor posição.

No Livro I do Foro Real encontramos, logo no primeiro título, as seguintes afirmações:

Nostro Senhur Ihesu Cristo [...] pôs el rey en seu logar [...].

$(F o R, \mathrm{I}, 128)$ 
Na Primeyra Partida defende-se ponto de vista semelhante. Assim, declara-se no início do Prólogo:

Os grandes logares que tẽẽ de Deus os rreys eno mundo [...].

(PrP, Pról., 16-17)

E ainda refere um pouco mais adiante:

[...] o gram logar en que nos pôs fazendonos senhores de tã boas gentes e de tã grandes terras como el quis meter so nosso ssenhõrio.

(PrP, Pról. 30-33)

Assim, o poder temporal é visto como devendo configurar-se segundo uma estrutura hierárquica que se faz repousar no modelo divino de organização da corte celestial.

O texto do Foro Real defende o modelo hierárquico do poder régio. Esta linha de argumentação invoca, em última análise, um plano divino, uma vez que é atribuída a Jesus Cristo a responsabilidade pela criação primordial deste modelo de estrutura hierárquica. Veja-se o seguinte excerto:

Nostro Senhur Ihesu Cr(is)to ordiou primeyramente ala en sa corte enos ce(os) e posse sy cabeça e começamẽto dos angios e dos archangos e quis e mandou que o amassem e guardassẽ come começamento e guarda de todo e depoys esto fez ome a maneyra de sa corte e|n| como [a si] auya posto cabeça e começo, pose ao home a cabeça encima do corpo e neella posse razõ [e] entendimento de como se deuẽ a guiar os outros nembros e como an de seruir e d'aguardar todos a cabeça mays qua a ssy meesmos. E disy ordyou a corte terreal enaquella meesma guysa que era ordiada en ceo: pos el rey en seu logo por cabeça e começamento de seu poboo todo, assy como posse si cabeça e começamento dos angeos e dos archangeos. E deulhy poder de guyar e de mandar.

(FoR, I, 119-129)

Pode, portanto, dizer-se que o mundo humano reflete uma imagem do mundo divino, se notarmos que Deus "ordiou primeyramente ala en sa corte [...] e disy ordyou a corte terreal enaquella meesma guysa que era ordiada en ceo:" (FoR, I, 119 [...] 128). Esta tese prolonga-se especificamente por uma outra dimensão, a saber, que esta mesma organização hierárquica segue também a imagem de um modelo natural somático, que é, de facto, frequentemente convocado em processos comparativos.

Esquematicamente, a linha de argumentação a que me estou referindo poderia ser representada do seguinte modo: 


\section{Comparação com base no Modelo Natural}

\section{Comparação com base no Modelo Natural}

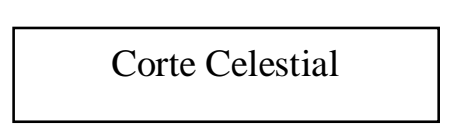

$$
\text { Modelo Natural Corpo }
$$

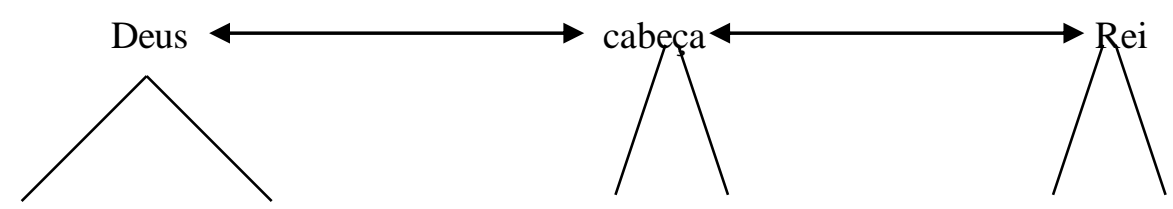

Anjos arcanjos membros

o seu povo

representação em que se vê a mesma organização hierárquica orientada que é proposta na Primeyra Partida.

Esta conceção hierárquica da sociedade é baseada na autoridade divina; e é também apresentada como fator de ordenação, de coerência, de organização da comunidade, que se diz corresponder à organização da corte celestial. Constitui um modelo de estruturação que se propõe e se pressupõe ser partilhado pelo receptor. O que assegura a sua aceitação e o êxito do procedimento retórico.

Em representação esquemática, teremos:

\section{Deus}

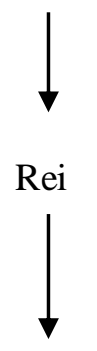

Povo

As linhas argumentativas analisadas prolongam-se diretamente numa outra, que remete para a necessidade de o legislador aliar ao seu poder um adequado saber.

No Foro Real, a definição do rei como cabeça do seu povo conjuga de modo feliz estas duas dimensões, pois através da metáfora se manifesta de modo tão expressivo quanto condensado a sua posição de proeminência e simultaneamente a sua 
condição de sede da razão e sabedoria. Constitui, portanto, uma dupla vertente da organização retórica.

Noutros passos do texto do Foro Real, ocorrem casos em que se estabelece uma relação analógica organicista ou somática que segue provavelmente, como no caso já referido, o modelo retórico da pregação cristã. Atente-se nos dois exemplos seguintes:

[...] como se deuẽ a guiar os outros nembros e como an de seruir e d'aguardar todos a cabeça mays qua ssy meesmos.

$($ FoR $, \mathrm{I}, 125-127)$

Assy como nẽhuu nẽbro nõ pode auer saude sen sa cabeça, assy nẽhuu poboo nõ pode auer sen seu rey que é sa cabeça [...].

(FoR, I, 148-151)

Há aqui, na verdade, uma tentativa de reprodução da organização hierárquica do corpo na estruturação hierárquica do estado, definindo axiomaticamente a cabeça como centro de controle e orientação dos membros e o rei como entidade organizadora de seu povo. A relação analógica verifica-se de elemento a elemento e de estrutura a estrutura, ou seja, define um isomorfismo. A explicação organicista define metaforicamente o rei como cabeça do seu povo e a partir da posição fisiológica superior da cabeça deduz-se uma fundamentação biológica da necessidade de existência do poder de um chefe.

Interessa, entretanto, anotar que nem sempre a comparação organicista está associada à matéria das Escrituras: por vezes, agrega o que "se quer definir ou demonstrar" a modelos naturais, biológicos, pressupostamente disponíveis no conhecimento do recetor. Leia-se o exemplo seguinte:

Ca bẽ assi como do coração do homẽ rreçebẽ todolos outros nenbros vida, assi da Sancta Eygreia rreçebem benffeitorias e mantijmẽto todos os que a seruirem.

$$
(\operatorname{Pr} P, \mathrm{XIX}, 10-12)
$$

O texto da Primeyra Partida sublinha particularmente a relação de implicação existente entre a sabedoria do rei e o "fazer a justiça", defendendo que o rei não apenas está investido de poder, como também tem de dominar um saber, que deve decisivamente moldar a aplicação da justiça.

Ao longo do Prólogo, é notória a insistência nesta relação de estreita articulação entre "saber" e "fazer a justiça": os dois termos são sistematicamente aproximados, a ação depende do conhecimento entendido como reconhecimento da verdade. Esta asserção é retirada de afirmações de el-rei Salomão considerado como o rei justo por excelência. Na figura deste modelo dá-se a síntese da argumentação anterior: ele reúne em si os dois valores - 'saber' e 'fazer a justiça' -, uma vez que este rei é apresentado axiomaticamente como "muy sabho e muy justiçoso". A sabedoria das suas sentenças torna-se um tópico que faz parte da enciclopédia do 'cristão' comum.

Como ficou patente, este discurso atribui um conjunto de valores positivos ao poder legislativo, retoricamente articulados a razões de vária índole, em princípio conhecidas e aceites: 
- institucional, porque legislar é prerrogativa do poder régio;

- pessoal, porque este rei alia à sua posição hierárquica superior, a sabedoria

- social, porque a lei assegura o bem-estar do povo e a manutenção da paz;

- e ainda ética, porque o "direito" se identifica com o bem.

Interessa referir que, na sequência se defende uma tese específica: se o rei conhece o que é verdadeiro e direito, a sua figura de rei identifica-se com a Justiça e o Bem, de tal modo que a simples visão do rei desfaz o mal. O rei personifica a justiça. E o texto da Primeyra Partida retoma a afirmação inicial da relação entre "saber" e "fazer a justiça", formulando-a agora como uma sequência ordenada, percorrida por um mecanismo de implicação. Leia-se:

E por esta rrazõ fazemos assinaadamẽte este liuro por que senpre os rreys do nosso senhorjo se catẽ en el assy como ẽ espelho e veiã as cousas que en ssy am de enmendar e as entendã. E ssegundo aquisto façã enos seus rreynos.

(PrP, Pról, 67-70)

\section{Em esquema:}

senpre os rreys se catẽ en el assy como ẽ espelho $\rightarrow$ e veiã as cousas $\rightarrow$

e as entendã $\rightarrow$ e ssegundo aquisto façã enos seus rreynos.

É muito clara a progressão de uma perceção física para a perceção intelectual patente na sequência dos predicados: olhar (catar) $\rightarrow$ ver $\rightarrow$ entender; e só atingindo o nível mais elevado da apreensão cognitiva do mundo, é aconselhável/ aconselhada a ação legislativa. Justifica-se, pois, a existência da Primeyra Partida, definindo-a como um 'espelho de sabedoria que serve de base ao conhecimento que permitirá ministrar a justiça'. Propõe-se no passo citado um jogo de imagens que motiva a repetição dos termos "catar" e "ver" - sendo que o rei reflete a Justiça e o Bem, e se revê neste livro, que é espelho de sabedoria.

O exercício da justiça, que envolve de modo central a capacidade de distinguir entre o Bem e o Mal e de promover o bem premiando os bons e suster o mal castigando os maus, assegura o Bem Comum e mantém o povo em paz. A evocação da fé católica é pretexto para sublinhar o previsto julgamento "dos bons e dos maus" e para salientar que todos estarão sujeitos a esse juízo final.

O poder de castigar os maus tem talvez a sua mais interessante expressão numa comparação de estrutura caracteristicamente alegórica que inicia o Título II $^{\circ}$ do Livro I do Foro Real:

\footnotetext{
Assy como a infirmidade e a chaga que é grande eno corpo nõ pode saar sẽ grandes maestrias nẽ sẽ grandes meezinhas por ferro e por queymas, assy a maldade dos que sõ endurados e perfyosos en fazerlhys mal non tha poden toller senõ per graues pẽas, ca o diz a Escriptura que [...]. $\quad$ (FoR, I, 83-87)
}

A analogia é, também aqui, organicista ou de inspiração somática. Procura-se, neste caso, fundamento e suporte quer suscitando diretamente os textos e a doutrina do cristianismo, as Escrituras, quer usando meios de expressão que lhe são próprios, a 
linguagem alegórica. Há que sublinhar que a invocação da justeza ética da lei, a afirmação convicta da sua moralidade e a insistência na tese de que ela assegura a manutenção do povo em paz e o bem comum trazem para os textos em estudo momentos argumentativos em que prepondera a manifestação de um pathos de amplos efeitos mobilizadores.

Nos textos do Foro Real e da Primeyra Partida fica delineada uma articulação forte entre a concepção do Poder e a concepção da Justiça. O esquema seguinte pretende explicitar essa articulação:

\section{VONTADE DE DEUS}

\section{AUTORIDADE SUPREMA}

$$
\mid
$$

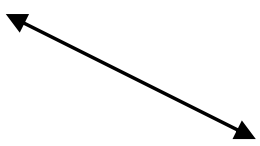

Príncipio

Ético / Moral

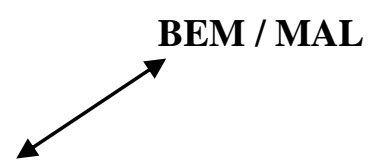

Destrinçar

O BEM E O MAL

Investe o Rei

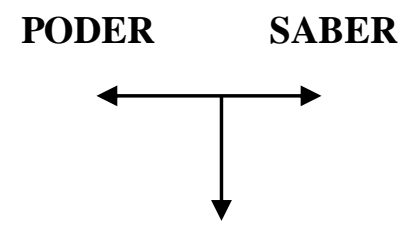

VONTADE do Rei

FAZER

Deôntico

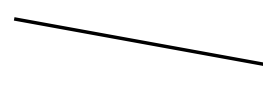

BEM PREMIADO

SALVAÇÃO

BEM COMUM

POVO EM PAZ

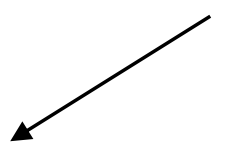

MAL CASTIGADO 
A imagem do rei como cabeça do seu povo conjuga, através da metáfora, duas dimensões: a da sua posição de proeminência e simultaneamente a da sua condição de sede da razão e sabedoria.

Mas não é só na definição do poder régio que encontramos a metáfora da cabeça como sede do poder. Por extensão, torna-se o tópico retórico de qualquer forma de poder. No texto da Primeyra Partida há numerosas ocorrências de que selecionei alguns exemplos:

E por isso lhy rrespondeu: tu es Pedro, que quer tãto dizer come cousa firme en creença por que creeu sen në hüa duuyda e outorgou que elle era Filho de Deus. E outrossy a elle disse: tu seeras chamado Chephas que quer tanto dizer como cabeça ca assy como a cabeça he sobrelos outros nëbros, assy Sam Pedro foy sobrelos outros apóstolos todos. E por esso he chamado cabedel delles. E por ende o apostoligo que tem logar de Sam Pedro he cabedel de todos os bispos assy como ffoy Sam Pedro cabedel sobre todos os apostolos. (PrP, VIII, 87-96)

Estabelece-se uma analogia organicista, associada a um modelo natural, biológico; identifica-se a cabeça como centro de controle e decisão "sobrelos outros nẽbros", e da posição fisiológica superior da cabeça infere-se, por sugestão da comparação, a posição superior de Pedro "sobrelos outros apostolos todos".

Nos restantes casos a criação retórica do modelo é a mesma:

E por esso cõueo que ouuesse estes dous nomes papa e apostoligo e que sse ajütasse en hüa pessõa que ffosse cabeça de todolos outros prelados assy como he dito. Onde por todas estas cousas e por estas rrazões deue o apostoligo seer moyto onrrado e aguardado come aquel que he padre das almas e ssenhor e mãteedor da ffe.

(PrP, VIII, 113-116)

[O Papa] he cabeça da Santa Jgreia /.../ E ajnda onrrã a toda a cristaydade cuia cabeça he come ordinhador e mãteedor da fe.

(PrP, VIII, 205-207)

E a outra por que onrrandoos onrrã a Santa Jgreia cuios seruidores som e a ffe de Nostro Senhor Ihesu Cristo que he cabeça delles por que ssom chamados cristãos (PrP, IX, 1470-1472)

A IIIa [excomunhão] he se algũũ diz que a Jgreia de Roma nõ he cabeça da fe ou nõ lhy quer obedecer". ( $\operatorname{Pr} P, \mathrm{XII}, 67-68)$

E pero lho marido outorgue de começo se depois lhy demãdasse que o nõ fezesse, bë pode a molher yr contra o que prometeu. $\mathbf{E}$ esto he por que o homë he senhor e cabeça da molher. ${ }^{5}$ (PrP, XXVI, 331-334) 
Este procedimento de representação do Poder em imagem antropomórfica é frequentemente convocado em processos comparativos. Revela-se assim uma estratégia já codificada em competência na língua, de modo que podemos encontrá-la em diversos contextos em que se define 'Poder'. A metáfora torna-se parte dos saberes dos membros da comunidade, como um topos retórico, conhecido e invocado pela sua eficácia préassegurada.

Está claramente subjacente uma concepção organicista da realidade, que faz corresponder partes isoláveis dessa realidade a partes do corpo. A transição entre dois campos diferentes e a própria afirmação da analogia não são de apreensão problemática, como se nota no seguinte exemplo, sobre os catorze artigos do Credo que fundamentam a crença:

\footnotetext{
Nome tomarõ os articulos dos artelhos ca tanto quer dizer articulo come artelho ca bẽ assy como enos dedos da mão há XIIII artelhos outrossy ena fe ha XIIII artigoos como dito auemos. E assy como os artelhos fazẽ dedos e dos dedos mão que sse abre e se sarra, e filha e leixa, e toma e dá, assy os artigoos da Santa Jgreia ajũtados en hũu fazẽ a creença e fazẽ a fe que he assy come mão que mãtem a ley de Deus [que] sarra a abre e prende e leixa e toma e dá. Onde destes logares foy tomado o nome dos articulos. ( $\operatorname{Pr} P$, II, 345353)
}

Encontramos, neste passo, uma analogia organicista ou somática inspirada na etimologia. Justifica-se o número dos artigos e a própria designação recorrendo a uma comparação que faz corresponder o número catorze ao número de articulações de uma mão, atribuindo eventualmente um sentido oculto ao referido número (tradição supersticiosa da cabala). Não se trata de uma correspondência apenas numérica, mas também funcional /estrutural; o modo articulado como os artelhos constituem os dedos e estes a mão corresponde ao modo como os artigos se constituem em crença e desta se passa à fé; a estrutura e funções da mão (consideradas igualmente em três momentos) são comparadas às da fé.

Figuram repetidamente, nos textos analisados, analogias organicistas ou somáticas com raízes antigas na tradição do cristianismo, nomeadamente em São Paulo. Recordese que já São Paulo falava da Igreja como corpo de Cristo (I Cor. 12, 12-18; Ef. 1, 22 ss.).

A argumentação baseada em comparações tenta suscitar um raciocínio de tipo analógico. A analogia é um processo muito rentável para a dedução de significações: facilita a apreensão (e aceitação) de novos conceitos aproximando-os de conceitos já adquiridos que fariam parte da enciclopédia do falante-ouvinte comum, constituindo por hipótese um conjunto de tópicos ou imagens, prefigurados no público da época e que estariam à partida consolidados. A adesão do receptor, o seu posterior empenhamento, estão razoavelmente assegurados e o êxito do argumento assim construído é muito provável. Completa-se, pois, o processo de persuasão. E nesse processo utiliza-se, portanto, a estratégia de invocar tópicos retóricos já disponíveis no conhecimento e experiência e a aproximação a 'coisas' conhecidas e naturais que permitem a assimilação de conteúdos. 
A comparação e a alegoria pretendem suscitar um raciocínio analógico, mas mantêm em paralelo os dois 'mundos' confrontados, não se verificando a translação/ transporte entre dois campos semânticos, como seria próprio da metáfora. Este tipo de estratégia tem frequentemente inspiração organicista ou somática como foi observado, suscitando assim a motivação e a força de demonstração do modelo natural. E o uso do modelo natural permite, como já foi referido, o sucesso do processo comunicativo.

As estratégias de argumentação que observámos visam dois objetivos:

- a legitimação da autoridade de que depende o discurso legislativo;

- a sedução, e mesmo manipulação dos destinatários no sentido de os fazer aderir a certas normas e aceder aos comportamentos desejados.

Convém lembrar que uma argumentação eficaz tem de prever mais do que uma recepção, tem de ter em conta a diversidade dos destinatários e ponderar os argumentos utilizados. Os argumentos disponíveis não são necessariamente universais e podem ter um efeito retórico e um rendimento variável conforme o auditório a que são dirigidos. Para uns será mais sugestivo e eficaz o argumento do Bem Comum, para outros o da vontade de Deus, para outros ainda o bem individual ou o medo do castigo e da pena; e serão ainda avaliados de variadas formas a promessa da salvação eterna ou a ameaça da eterna danação. Ou seja, a multiplicidade de estratégias e de argumentos utilizados nestes textos visa uma argumentação eficaz tendo em conta a diversidade de públicos.

Podemos observar outros movimentos retóricos que exemplificam o recurso ao modelo natural:

E o tẽpo deue catar que nõ sarmõe cada dia, mays en sazões cõ[tadas] e guysad[a]s ca sse ssenpre chouesse nũca leuaria terra fruito

$$
\text { (PrP, VIII, 1089-1091) }
$$

O raciocínio parte de um modelo natural, biológico, sobejamente conhecido por Locutor e Alocutário, que poderia ser equacionado do seguinte modo: 'assim como a terra demasiado molhada não produz fruto, assim o sermão demasiado repetido dá "nojo" aos homens e não frutifica'

O mesmo dispositivo - o recurso à evocação de um modelo natural - é também visível no seguinte exemplo:

Ca assy como os peyxes nõ pode viuer sena agua outrossy os rreligiosos nõ podẽ fazer bõa vida fora da claustra porque perdẽ a uida perdurauil.

$(\operatorname{Pr} P, \mathrm{X}, 713-715)$

Nesta Lei 29 do título $\mathrm{X}^{\mathrm{o}}$ da Prymeira Partida, ordena-se determinada pena para os religiosos que saiam dos mosteiros. O receptor descodifica facilmente a primeira afirmação - que se poderia glosar por 'os peixes, fora da água, perdem a vida'; a comparação sugere que o claustro é o meio ambiente natural dos religiosos, dando a inferir uma afirmação nova - 'os religiosos, fora do claustro, perdem a vida (eterna)'.

A utilização pelo Locutor na ordem argumentativa de elementos de carácter racional, objetivados na convocação e ativação de dimensões da ordenação cognitiva do mundo, que suportam argumentação-justificação fundada na razão, na consideração de raciocínios apoiados em nexos de causalidade e também de proximidade e analogia. 
Vem a propósito referir que tais elementos recortam no discurso a presença de um logos matizado de elevada força argumentativa - logos que especificamente complementa, e é complementado, por um não menos matizado pathos.

Frequentemente aliam-se diversas tendências argumentativas como acontece na Lei $\mathrm{XL}^{\mathrm{a}}$ do Título $\mathrm{VIII}^{\circ}$ da Primeyra Partida em que se verifica o recurso a citações sucessivas. A estrutura desta lei associa duas estratégias argumentativas: apresenta uma alternância entre o relato de discurso de autoridades, procedimento retórico frequente e eficaz e a utilização de comparações que mobilizam a experiência e o conhecimento do mundo partilhados por Locutor e Alocutário. O seguinte excerto, sobre a pregação, permite comprová-lo:

\begin{abstract}
Ca [d]a primeira disse Sam Paulo que sse o preegador dissese tã bẽ sa rrazõ que ssemelhasse bem aos que [o] ouv[i]ssem que falaua da boca do angio [...]. Da ssegũda disse Sam Gregorio que sse o preegador ffazia maa vida que he despreçada [...] E o preegador que tal he pono en semelhãça de cijza que deita adecoada e laua as outras cousas e ella fica lixossa en sy. E põlhy outrossy semelhãça de cal de pedra per que $\mathrm{p}$ [a]ssam as aguas claras e linphas [...] pero nõ fazẽ prol aa pedra nẽna amolẽta ante fica aspera e dura como era. E ssemelha outrossy a candea que arde e queimasse ssi meesma e alumea as outras cousas e ella nõ rrecebe prol de sseu lume. E destes disse o apostolo Sam Pedro que erã ataes come ffontes sem aguas e como as neuoas que uoluẽ os uẽtos [...] E outrossy disse Sam Gregório que os prelados que fazẽ maa vida que tantas peas mereçẽ quantos exẽplos maos derõ a sseus meores. (PrP, VIII, 1065-1085)
\end{abstract}

Temos quatro vezes a citação da autoridade de São Paulo, São Pedro e São Gregório. Estas vozes, reconhecidas, ouvem-se ao longo do texto, sendo convocadas em diferentes momentos específicos; e o Locutor, quando cita, não cede, naturalmente, a sua voz a uma voz qualquer. Verifica-se um critério de seleção que convoca aqueles que são reconhecidamente autores de textos ou que são citados nas Escrituras.

Além das citações vemos que os conteúdos informativos são integrados ou reativados no conjunto de saberes do Alocutário com mobilização da sua experiência e da sua enciclopédia: nesta figuram as propriedades agora invocadas, da cinza, da cal de pedra, do lume e das candeias, e da água das fontes e das névoas e dos ventos.

A autoridade divina é a mais frequentemente solicitada, e essa invocação apresenta duas vertentes: uma que define Deus como poder superior, outra que salienta a função primordial, criadora, da palavra divina. Veja-se o seguinte excerto:

E esto he a ssemelhança do carpenteyro ou do maestre que ffaz a obra que com aquela fferramẽta que faz hũũ lauor fara outros [...] $\mathrm{E}$ a fferramẽta de Deus con que fez todalas cousas nõ foy senõ pela ssa parauoa soo. Ca aly hu el fez o mundo nõ ouue hy mays desto senõ que disse que ffosse feyto e foy logo assy. E esto diz a propheta David (e) enoutro logar que polo uerbo de Deus som os çeos firmados e toda a uertude delles he eno Spiritu Santo. $E$ ainda sen esto o amostra Sam Johãne euangelista mays conpridamẽte que todos, quando disse que Deus era palaura e que a palaura era Deus e Deus era palaura. ${ }^{6}(\operatorname{Pr} P, \mathrm{III}, 505-516)$ 
Sublinho que este exemplo ilustra duas estratégias argumentativas muito típicas da Primeyra Partida. Por um lado, o Locutor parte da explicitude de uma comparação que usa como comparante um elemento do conhecimento comum e, por outro lado, utiliza citações (duas) que acompanham a asserção e a reforçam.

Registo que esta soberana importância atribuída à palavra divina explica já a utilização da citação das Escrituras como a mais frequente estratégia de legitimação do discurso neste texto - embora, na verdade, tal não aconteça apenas na Primeyra Partida. Os argumentos de autoridade que invocam Deus ou as Escrituras são, pois, eficazes, porque se trata de uma autoridade axiomática, baseada em raciocínios que não necessitam de ser demonstrados, pois emanam do ser infalível, perfeito. ${ }^{7}$

Não se deve ignorar que não é fácil determinar o grau de prestígio que detinham na época de redação destes textos - sensivelmente em meados do séc. XIII - os diversos autores da tradição cristã. Apercebemo-nos, no entanto, de manifestas preferências que o texto revela. Assim, na Primeyra Partida são mais citados São Paulo, como autor de numerosas epístolas, e São Pedro, pelas suas ações, mas também pelas suas palavras; segue-se S. João Evangelista, apresentado, como acima referi, como autor do Evangelho e do Livro do Apocalipse, livro "de muy grandes puridades que lhy el [Jesus] mostrou" (PrP, Pról, 175). ${ }^{8}$ É ainda citado frequentemente o rei David também acima mencionado, autor do "Salterio", obra onde estão reunidos os seus salmos, e também o rei Salomão, Santo Agostinho, e, mais esporadicamente, alguns outros, como S. Jerónimo e S. Gregório. É pelo registo e divulgação da palavra divina que são invocados, na condição de autores de "textos" do Cristianismo. E afirma-se frequentemente que esta autoria assenta no "auxílio do Espírito Santo" - o que em muito a credibiliza.

O prestígio das autoridades invocadas está muitas vezes duplamente sublinhado: para além de divulgarem a palavra divina, têm um estatuto próprio que lhes confere individualidade. Assim, por exemplo, Salomão surge sempre associado às expressões "foy muy sabio", "foy sabedor" ou "foy muy sabho e muy justiçoso". David, também frequentemente citado, é referido como rei e antepassado de Jesus Cristo, mas sobretudo pela excelência dos seus textos.

Algumas das autoridades citadas dispensam qualquer apresentação: estão neste caso Jesus Cristo, os apóstolos, os santos e algumas figuras do Antigo Testamento como os patriarcas ou os profetas. A menção de outras, porém, é acompanhada de uma estrutura de encarecimento retórico que justifica a sua utilização como autoridade ou modelo exemplar. Veja-se, a título de exemplo, a referência a "Nabocadonosor o grã rrey de Babilonia" (PrP, IIII, 340), a "Nicodemos que era homẽ de que (Jesus) fiaua e lhy dizia algũas das sas puridades por que o tî̉ha por dereyto e de bõa vida" $(\operatorname{Pr} P$, IIII, 370-372) ou a "Aristotiles que foy phylo $<$ so $>$ pho grande" ( $\operatorname{Pr} P, \mathrm{VII}, 157)$.

Com o objetivo de suportar adequadamente as suas posições, o Locutor convoca ainda a 'voz' de Princípios, Normas ou Verdades Gerais, previsivelmente partilhados e aceites pelo Alocutário. Estas vozes, presentes no discurso e nele muito atuantes, recortam uma zona particular da estratégia retórica que se estabelece, segundo modalidades diversas, nestes textos legislativos.

Sem querer prolongar a análise das marcas linguísticas direi apenas que tais elementos integram geralmente segmentos de carácter justificativo, sendo regularmente 
introduzidos por enunciados com conector causal, que precedem ou seguem os atos diretivos do discurso legislativo.

Creio ter podido mostrar, ao longo da análise aqui apresentada do Foro Real e da Primeyra Partida, que se observa nestes textos legislativos a utilização sistemática de certo tipo de estratégias, que se podem resumidamente recapitular:

(i) Preferência manifesta por argumentos que se baseiam em autoridades, nomeadamente a inquestionável autoridade divina ou das Escrituras, ainda que não se prescinda do recurso a autoridades humanas legitimadas pelo prestígio do seu "saber", "entendimento", "siso" ou "bondade". Preconiza-se também a necessidade de existência de uma estrutura hierárquica do poder temporal que se faz repousar no modelo (divino) de estruturação da corte celestial e em modelos naturais somáticos. Não se torna muito difícil verificar a afinidade do modelo hierárquico proposto no Foro Real e na Primeyra Partida uma vez que se constrói do mesmo modo (utilizando as mesmas palavras e propondo a mesma ordenação). O texto da Primeyra Partida defende o modelo hierárquico do poder régio, mas alia a este poder a necessidade do saber, manifestando a preocupação de propor o modelo do rei sábio;

(ii) Recurso obstinado a raciocínios de tipo analógico - o que explica a frequente ocorrência de comparativas; a analogia é um processo muito rentável para a dedução de significações: facilita a apreensão (e a aceitação) de novos conceitos aproximando as novas asserções de conceitos já adquiridos que fariam parte da enciclopédia do falante/ ouvinte comum, constituindo, por hipótese, um conjunto de tópicos ou imagens prefigurados no público da época e que estariam à partida consolidados. A adesão do Alocutário e o seu posterior empenhamento na ação estão razoavelmente assegurados e o êxito do argumento assim construído é muito provável. Completa-se, portanto, o processo de persuasão. Este tipo de estratégia tem frequentemente inspiração organicista ou somática suscitando assim a motivação e a força de demonstração do modelo natural. Por vezes, os raciocínios de tipo analógico tomam a forma de recursos retóricos mais complexos, de marcado cariz alegórico. Igualmente relacionada com a frequência de comparativas está a argumentação que recorre a modelos exemplares que se propõem para imitação (ou anti-modelos cuja conduta condenável se deve evitar ${ }^{9}$ );

(iii) Ativação de doxas certamente disponíveis na comunidade: não só, genericamente, a voz plural que afirma que o bem deve ser recompensado e o mal punido, mas também outras normas ou verdades gerais a que o Locutor dá voz. O seu discurso é, portanto, polifónico; se se trata de polifonia concordante, harmoniosa, a adesão do Alocutário está já preparada de antemão, pois estará previamente convencido das premissas argumentativas, que reconhece, sendo, então, apenas preciso reativar a motivação para o levar a adotar os comportamentos desejados.

A identidade de objetivos explica a semelhança de meios utilizados nos dois textos em que se manifesta o discurso legislativo justificativo, havendo partes que se correspondem e até partes iguais. As estratégias de argumentação que observámos são variadas e visam, entre outros e acima deles, dois objetivos centrais:

- a legitimação da autoridade de que dependem os atos injuntivos que constituem o discurso legislativo propriamente dito; 
- a sedução e mesmo manipulação dos destinatários no sentido de os fazer aderir a certas normas e aceder aos comportamentos desejados.

Convém lembrar, a este propósito, que uma argumentação eficaz tem de prever mais do que uma recepção, tem que ter em conta a diversidade dos destinatários e ponderar os argumentos utilizados. Os argumentos disponíveis não são necessariamente universais e podem ter um rendimento variável conforme o auditório a que são dirigidos. Assim, para uns será mais sugestivo e sobretudo mais eficaz o argumento do Bem Comum; para outros o da vontade de Deus; para outros ainda o bem individual ou o medo da pena; e serão ainda provavelmente avaliadas de variadas formas a promessa da salvação eterna ou a ameaça da eterna danação. Ou seja, a multiplicidade de estratégias e de argumentos utilizados visa uma argumentação eficaz tendo em conta a diversidade de públicos.

Ficou patente que, em diversas leis, o termo de comparação é um Modelo exemplar, de autoridade inquestionável, frequentemente baseado em afirmações extraídas da Bíblia. Mas a estratégia de justificação observada não usa exclusivamente a comparação com a matéria das Escrituras. O procedimento é aplicado em casos em que não se verifica recurso direto ao "exemplum" divino. Assim, estas comparações agregam também com relativa frequência "o que se quer demonstrar" a modelos naturais ou da experiência que estão disponíveis na enciclopédia dos falantes e são partilhados por Locutor e Alocutário.

Pode tratar-se de um modelo de tipo biológico como, por exemplo, a noção da posição da cabeça em relação aos membros ou da relação genética entre pai e filho. Pode também ser baseada na experiência ou código comportamental, como, por exemplo, o conceito da relação e dos deveres dos pais para com os filhos, ou como o conhecimento das propriedades de certas substâncias - como o sal, que protege e preserva, ou a cal e a cinza, que têm uma natureza paradoxal e funcionam como filtros ou purificadores. Finalmente, a comparação pode invocar um modelo da mais simples evidência, como a constatação de que a luz ilumina e permite a visão. ${ }^{10}$

Estas estruturas justificativas, com linhas de argumentação introduzidas por causais, mas baseadas em comparações como meio de demonstração/prova de uma asserção-tema, seguidas por conclusões parciais e finais que retomam o tema, embora sejam frequentes no texto da Primeyra Partida não são exclusivas desse texto. Também se encontram noutros textos jurídicos; e recordam as técnicas ou procedimentos das "artes de pregar" que se estabeleceram e consolidaram sob forma preceptiva desde finais do séc. XII e ao longo do séc. XIII, dando origem a um "género" retórico mais ou menos estabilizado.

Como já referi no início deste artigo, essa semelhança indica que deveria existir alguma doutrina retórica sobejamente conhecida na época da redação dos textos jurídicos aqui analisados e típica de textos destinados à pregação, mas não exclusiva destes. Na legislação patente nestes textos, pretende-se conduzir o Alocutário a uma determinada prática. Há, portanto, razões para crer que este "género retórico" que visa o convencimento/sedução, estabelecido ao longo dos séculos na prática sermonística, não era exclusivo da pregação de carácter religioso, sendo também utilizado, por exemplo, nos sermões académicos ou nos textos jurídicos desde meados do século XIII. Este tipo de estratégia de "pregação" está constantemente envolvida na estruturação textual da Primeyra Partida e tem uma presença considerável, mas mais esporádica, no Foro Real, estando também presente em diversos aspectos da sua estrutura textual. 
Não será fácil recriar por conjetura o conjunto de valores partilhados e aceites pelo grupo mais ou menos restrito dos eventuais destinatários do texto da lei, o que equivaleria à definição do conjunto de topoi ou doxas que configuram o universo de crenças desse mesmo grupo; mas o carácter menos definido das coordenadas desse conjunto não inviabiliza que sejam tomadas em consideração.

Todo o texto tem uma dimensão acional. E em particular o texto jurídico legislativo. De facto, neste tipo de discurso deôntico-argumentativo, o aparecimento de argumentação está certamente ligado a uma antecipação de dúvidas, hesitações, ou mesmo objeções (um eventual contradiscurso) desse destinatário-tipo que é, em primeira instância, o futuro aplicador da lei; inscreve-se, portanto, numa preocupação de exaustividade, de explicitude e de convencimento / persuasão, tornando particularmente notória a interação e a presença efetiva de um Alocutário, por vezes individualizado, mas geralmente indiferenciadamente coletivo.

O objetivo da análise era efetuar um levantamento dos elementos destas estruturas textuais que fossem pertinentes para a exemplificação de certas estratégias argumentativas repetidamente utilizadas nestes textos, que configuram o discurso justificativo e que, tal como se foi aqui defendendo, são um elemento da sua caracterização.

Como foi longamente analisado, é muito frequente nos textos estudados a estratégia de evocação de argumentos baseados na autoridade, no comportamento de personagens exemplares e na analogia com modelos orgânicos, naturais. E são utilizados na ordem argumentativa elementos de carácter racional, objetivados na convocação e ativação de dimensões da ordenação cognitiva do mundo, que suportam uma argumentação-justificação fundada na razão, na consideração de raciocínios apoiados em nexos de causalidade e também de proximidade e analogia, dotando a construção retórica de um elevado grau de coerência textual.

\section{Bibliografia}

AMOSSY, Ruth. La notion d'ethos de la rhétorique à l'analyse de discours. In: Amossy, R. (ed.) Images de soi dans le discours: la construction de l'ethos. Lausanne: Delachaux et Niestlé, 1999, pp. 9-30.

ANSCOMBRE, J. La théorie des topoï: sémantique ou rhétorique?. Hermès, La Revue 15 (1), 1995, p. 185-198.

ANSCOMBRE, Jean-Claude; DUCROT, Oswald. L'argumentation dans la langue. Bruxelles: Pierre Mardaga éditeur, 1983.

BARROS, C. Versões Portuguesas da Legislação de Afonso X - Estudo Linguísticodiscursivo. Porto: U.Porto Editorial, 2010. 
BARROS, C. Convencer ou Persuadir: Análise de algumas estratégias argumentativas características do texto da Primeyra Partida de Afonso X. Cahiers de Linguistique Hispanique Médievale 18-19, 1994, p. 403-424.

BARROS, C. Fragmentos do texto das Partidas em português: análise de estruturas discursivas. In: Negro Romero, M.; Álvarez, R.; Moscoso Mato, E: (eds.) Gallaecia. Estudos de linguística portuguesa e galega. Universidade de Santiago de Compostela Publicacións 2017, pp. 251-265.

BRAGA da CRUZ, G O Direito Subsidiário na História do Direito Português. Revista Portuguesa de História XIV, 1975, p.175-316.

BROWN, G., YULE, G. Análisis del Discurso. Madrid: Visor Libros, 2005.

CASTRO, Ivo. Introdução à História do Português. Lisboa: Edições Colibri, 2006

CHARAUDEAU, P. ; MAINGUENEAU, D. Dictionnaire d'Analyse du Discours, Paris: Seuil, 2002.

FONSECA, J. Pragmática Linguística, Introdução, Teoria e Descrição do Português, Porto: Porto Editora, 1994.

GEE, J.P.; HANDFORD, M. (eds.). The Routledge Hanbook of Discourse Analysis. Abingdon: Routledge, 2012.

LEECH, G. Principles of Pragmatics. London: Longman, 1983.

MATTOSO, José. Identificação de um país. Lisboa: Temas e Debates, 2015.

JUCKER, Andreas. Historical Pragmatics. Pragmatic Developments in the History of English. Amsterdam: John Benjamins, 1995.

FOSS, Sonja K.; FOSS, Karen A.; TRAPP, Robert. Contemporary Perspectives on Rhetoric. 30 ${ }^{\text {th }}$ Anniversary Edition. Long Grove: Waveland Press, 2014.

KABATEK, J. Tradição discursiva e gênero. In LOBO, T.; CARNEIRO, Z.; SOLEDADE, J.; ALMEIDA, A.; RIBEIRO, S. (orgs). Rosae: linguística histórica, história das línguas e outras histórias [online]. Salvador: EDUFBA, 2012, pp. $579-588$

KABATEK, J. (ed.) Ibero-Romance: Corpus Linguistics and Historical Linguistics

Beihefte zur Zeitschrift für romanische Philologie 405, 2016.

KERBRAT-ORECCHIONI, C. Le discours en interaction. Paris: Armand Colin, 2005.

MEYER, M. (ed.). De la métaphysique à la rhétorique. Essais à la mémoire de Perelman. Bruxelles: Editions de l’Université de Bruxelles, 1986.. 
MIRANDA MENÉNDEZ, F. Dimensões 'meta' nos textos jurídicos medievais. In: BRITO, A.; BARROS, C. (eds.) Linguística Histórica e História da Língua
Portuguesa: Actas do Encontro de Homenagem a Maria Helena Paiva. Porto:

Faculdade de Letras, 2004, pp. 227-237.

\footnotetext{
${ }^{1}$ Este texto é uma versão reformulada do trabalho apresentada no VII ${ }^{\circ}$ Simpósio Internacional de Estudos Celtas e Germânicos, realizado na Universidade Federal de Pelotas de 26 a 28 de novembro de 2018, com o título: Representações visuais do poder em textos jurídicos da Idade Média.

${ }^{2}$ Neste artigo retomo e desenvolvo algumas posições já assumidas em trabalhos anteriores. Sobretudo Barros, 2010, a publicação que contem a investigação empreendida na minha tese de doutoramento, e Barros, 2017.

${ }^{3}$ Utilizei as edições de J. de Azevedo Ferreira dos manuscritos existentes no Arquivo Nacional da Torre do Tombo: José de Azevedo Ferreira, Alphonse X. Primeyra Partida. Édition et Étude. Braga, 1980; José de Azevedo Ferreira, Afonso X. Foro Real, Edição e Estudo. Lisboa, 1987; trabalhei sobretudo com os textos editados, embora tenha recorrido também às concordâncias de formas, de que disponho, para o texto do Foro Real, e ao texto digitalizado da Primeyra Partida, para estabelecer as frequências de algumas formas e dados estatísticos que por vezes são necessários.

${ }^{4} \mathrm{Na}$ referência aos textos de que são retiradas as citações, adoto o seguinte esquema: (i) o primeiro elemento especifica a obra, através das seguintes abreviaturas: FoR para o Foro Real, e $\operatorname{Pr} P$ para Primeyra Partida ii) o número romano, que segue a abreviatura, especifica o Livro, no caso do Foro Real e o Título, no caso da Primeyra Partida; (iii) o(s) número(s) árabe(s) indica(m) a(s) linha(s).

${ }^{5}$ A expressão jurídica "cabeça de casal" mantém-se até hoje.

${ }^{6}$ Cf. Jo 1, 1-14

${ }^{7}$ Convém assinalar que a invocação da autoridade de Deus apresenta uma outra vertente - a que salienta a função primordial, criadora, da palavra divina.

${ }^{8}$ É deste autor a mais extensa citação que detetei nestes textos: ocorre na lei $\mathrm{XI}^{\mathrm{a}}$ do título $\mathrm{IV}^{\mathrm{o}}$ da Primeyra Partida, que, em dois terços do seu texto (correspondendo às linhas 505 a 538 do título IV $^{\circ}$ ), reproduz ipsis verbis o evangelho de S. João (Cf. Jo 13, 1-15), com interpolação de apenas uma linha (1.520) de comentário interpretativo do Locutor, com formato reformulativo, metalinguístico, introduzido por " $\mathrm{E}$ esto tãto quer dizer que [...]"

${ }^{9}$ A mais frequente estratégia de comparação com recurso a um anti-modelo utiliza a figura de Lucifer. A repulsa pela sua conduta deve conduzir a um comportamento que tende a evitá-la. Esta comparação é geralmente acompanhada de citação das Escrituras e a invocação do máximo bem que Deus fez a Lucifer funciona como medida (em proporção inversa) da pena que lhe foi aplicada. Há diversos exemplos deste procedimento retórico como o que se pode observar no Livro I do Foro Real (FoR, I, 143-146). Para evitar um alongamento excessivo da demonstração, não foram analisados exemplos de argumentação pelo modelo negativo, como Lucifer ou os 'maus diabos' por revelarem uma repetição do movimento retórico de comparação por recurso a um modelo, com mera inversão do pólo axiológico.

${ }^{10}$ Os casos de comparações aqui citados foram exemplificados nos exemplos analisados. A ordem da enumeração poderá não corresponder à ordenação dos exemplos, uma vez que esta obedece à estrutura da demonstração.
} 